\title{
Educational Social and Health Joint Bicoloral World \& SEU Program for HIV Positive Cambodian Children - Research Note
}

V. Saosetha (Ven Saosetha)1', M. Utesena (Martina Utesena)², S. Seckova (Silvia Seckova)², Z. Kubalikova (Zuzana Kubalikova)², J. Benca (Juraj Benca)², V. Sladeckova (Veronika Sladeckova) ${ }^{3}$, L. Bucko (Lesley Bucko)², A. Shahum (Andrea Shahum) 5 , K. Vichet (Keo Vichet) $)^{4}$, R. Vlcek (Robert Vlcek)2, M. Olah (Michael Olah) ${ }^{3}$, L. Hoin (Leanghoin Hoin)

${ }^{1}$ Bicoloral World NGO Branch for Phnompenh Sihanoukville, Kingdom of Cambodia.

${ }^{2}$ St. John Paul School of Missiology St. Elizabeth SEU University Polianky, Slovakia.

${ }^{3}$ Dept. of Tropical Diseases, Slovak Tropical Inst. Slovak Med University Bratislava, Slovakia.

${ }^{4}$ House of Hope, House of Family, House of Smile, St Elizabeth University HIV , Program in Cambodia, Phnompenh, Kingdom of Cambodia.

${ }^{5}$ Stamford Health Tully Healt Center, USA.

${ }^{6}$ Cambodian Children's Fund Phnom Penh, Kingdom of Cambodia.

\section{E-mail address:}

sao.setha@gmail.com

\section{Reprint address:}

Ven Saosetha

House of Family

Phnom Penh

Cambodia

Source: Clinical Social Work and Health Intervention

Volume: 12

Issue: 1

Pages: $23-25$

Cited references: 5

\section{Reviewers:}

Selvaraj Subramanian

Kualalumpur

Mageswari Rajoo

Kualalumpur

\section{Keywords:}

Pediatric HIV. Education. Orphans.

\section{Publisher:}

International Society of Applied Preventive Medicine i-gap

CSWHI 2021; 12(1): 23 - 25; DOI: 10.22359/cswhi_12_1_05 (C) Clinical Social Work and Health Intervention

\section{Abstract:}

In areas of higher HIV prevalence in Southeastern Asia, joint programs focused not only on HIV screening and detection in street children, but also joint strategies such as to bring children 
from street to school as well as full-board shelters. These are important because only HIV chemotherapy is sufficient to prevent reinfection and achieve adherence to medications mainly in children and adolescents in remission. This research note presents a 20 years comprehensive program for 105 children, $80 \%$ HIV positive in Phnompenh and Sihanoukville Kingdom of Cambodia centers.

\section{Introduction}

Prevalence of HIV in children in Southeast Asia is decreasing due to investments for prevention, active screening, education and highly active anti-retroviral therapy being available since 2010 for all children in the Kingdom of Cambodia for free(1). When in 1999-2001 the occurrence of HIV in large urban settings was $1-3 \%$ in children and $2-5 \%$ in adults. Currently after initiation of HAART in 2010 the numbers are steadily decreasing. This is to present a comprehensive program including sheltering, education, anti-malnutrition and HIV testing programs at two orphanages in Phnompenh and Sihanoukville running for 20 years.

\section{Setting and Methods}

This is a descriptive research note showing the successful combination of three strategies-education plus social work (housing \& nutrition) plus HIV management in a two tailed cohort of 105 children: 45 and 35 still sheltered or in halfway houses (adolescents) and 25 already left and running their own businesses and families (married); 38 plus 28 children still on anti-retroviral therapy in complete and 2 in partial remission in two social health education combined shelters serving orphans with full board and free HAART donated by the government.

\section{Results}

In 20 years, of 105 children, only 4 died and 4 were lost in follow up; $93 \%$ retained in one of the projects either full board shelter or half way housing as the guided way to independence; 14 completed our study in University. Only 4 severe complications of HAART occurred in last 5 years and none of children died from adverse drug reaction; despite about $30 \%$ to $40 \%$ having received concomitant treatment for tuberculosis. The staff, including one foreign doctor or social worker and 8 plus 5 local staff supervise school attendance, cultural and sport activities; adherence to anti-retroviral therapy; acceptance of local housing rules including 3-5 times daily food including meat and fresh fruit daily to ensure proper nutrition as a part of comprehensive psychosocial nutritional and anti-retroviral complex therapy of both HIV and their orphan status.

\section{Conclusions}

Children with HIV and TB need comprehensive approaches including positive psychosocial stimulation, effective anti-retroviral therapy, food rich in vitamin elements as part of anti-infectious complex management; motivational education. This is one of the explanations, why children in our project and other projects in Southeast Asia including Vietnam, Cambodia, Thailand, etc. have better outcomes as similar children in SubSaharan Africa where malnutrition and lack of school and educational support may be responsible for worse outcomes for pediatric HIV.

\section{References}

1. WORLD HEALTH ORGANISATION ANNUAL REPORT (2018) South East \& Western Pacific Region. WHO Geneve (2018) p 355.

2. MASAN J, SRAMKA M, SABO A, KALATOVA D, ROTTERMUND J, RUZICKY E (2020) The covid-19 disease situation prior to October 2020 in selected countries: the potentially severe consequences of Covid-19 on the nervous system and several key solutions to Covid-19 in relation to digitization and artificial intelligence. In: Acta Misiologica / Bucko Ladislav. - ISBN 2453-7160. - Vol. 14, no. 2 p. 112-126.

3. PERI H A, SUBRAMANIAN S, SLADECKOVA V, BYDZOVSKY J, DURCOVA B, KUBALIKOVA Z, OLAH M, MATULNIKOVA L, DOKTOROV A, BERESOVA A, KUBIK F, FULA M, OTRUBOVA J, KALATOVA D, 
KUKUCKOVA E, JURINOVA S, BENCA J, SHAHUM A, HOY LEANG HOINAND CHENG HOIN, SETA S/ Early detection of adverse therapy reaction in orphan children with AIDS (short communication) / In: Acta Missiologica. - ISSN 1337-7515. - Vol. 13, no. 2 (2019) p. 184-187.

4. SECKOVA $S$ et al (2016) 15 years of Follow up in Cambodian children with HIV. Clinical Social Work. 5.2016.33

5. KOTLAROVAZ (2020) Sexual Risk Behavior

- Prostitution. In Health and Social Work.

p. 64-69. ISSN 1336-8326. 